\title{
Elucidation of the Microbial Complex Having a Causal Role in the Development of Apple Replant Disease in Washington
}

\author{
Mark Mazzola
}

USDA Agricultural Research Service, Tree Fruit Research Laboratory, 1104 N. Western Avenue, Wenatchee, WA 98801. Accepted for publication 15 May 1998.

\begin{abstract}
Mazzola, M. 1998. Elucidation of the microbial complex having a causal role in the development of apple replant disease in Washington. Phytopathology 88:930-938.

Systematic studies were conducted to elucidate the role of different soil microbial groups in the development of apple replant disease. Populations of targeted microorganisms were reduced by the application of semiselective biocides and soil pasteurization. Bacteria were not implicated in the disease, because application of the antibiotic chloramphenicol reduced soil populations of bacteria but failed to improve growth of apple transplants, while enhanced growth was achieved at pasteurization temperatures that did not alter attributes of the bacterial community recovered from apple roots. Populations of Pratylenchus penetrans were below the damage threshold level in eight of nine orchards surveyed, and nemati-

cide applications failed to enhance apple growth in four of five replant soils tested, indicating that plant parasitic nematodes have a minor role or no role in disease development. Application of the fungicide difenconazole or metalaxyl enhanced growth of apple in all five replant soils, as did fludioxinil in the two soils tested. Soil pasteurization enhanced growth of apple and resulted in specific changes in the composition of the fungal community isolated from the roots of apple seedlings grown in these treated soils. Cylindrocarpon destructans, Phytophthora cactorum, Pythium spp., and Rhizoctonia solani were consistently isolated from symptomatic trees in the field and were pathogenic to apple. However, the composition of the Pythium and Rhizoctonia component and the relative contribution of any one component of this fungal complex to disease development varied among the study orchards. These findings clearly demonstrate that fungi are the dominant causal agents of apple replant disease in Washington state.
\end{abstract}

The poor growth of fruit trees that occurs after replanting on a site that previously supported the same or closely related species has been termed "replant disease" or "replant disorder." In apple, replant disease is widespread and has been documented in all of the major fruit-growing regions of the world (28). Apple replant disease is characterized by uneven growth of young trees but, when severe disease pressure is encountered, poor growth may be exhibited by a majority of trees on the site and death of young trees may occur. Symptoms of apple replant disease include severe stunting, shortened internodes, rosetted leaves, small root systems, decayed or discolored roots, and reduced productivity. Examination of root systems has shown that apple replant disease is associated with premature destruction of epidermal cells and cortical tissues and a marked reduction in lateral root development $(9,20)$; in addition, roots of declined trees possess very few functional root hairs (4).

In economic terms, replant disease has significant consequences due to the fact that the disease has a continuous influence on production for the life of the orchard. In addition to tree replacement costs incurred on sites exhibiting severe replant symptoms, trees affected by replant disease begin bearing fruit 2 to 3 years later than normal and fail to attain yields comparable to those obtained in orchards free of the disease. In Washington state, failure to control apple replant disease typically results in a $\$ 40,000$-per-acre reduction in gross returns over a 10-year period (24).

Although difficulty in reestablishing old orchard sites has been documented for over 200 years (14), the etiology of this disease phenomenon remains an enigma. The factors implicated as causal agents and predisposing factors have varied considerably between

Corresponding author: M. Mazzola; E-mail address: mazzola@tfrl.ars.usda.gov

Publication no. P-1998-0629-01R

This article is in the public domain and not copyrightable. It may be freely reprinted with customary crediting of the source. The American Phytopathological Society, 1998. geographic regions or between orchards in the same region. Apple replant disease has been attributed to numerous abiotic factors including low or high soil $\mathrm{pH}$, phytotoxins, unbalanced soil nutrition, heavy metal contamination, poor soil structure and drainage, and cold or drought stress $(14,28,31)$. Although these elements may contribute to tree growth problems, the fact that other fruit trees planted in the same soil grow normally (21) and that soil pasteurization $(9,11)$ or fumigation $(14,23)$ dramatically improve plant growth provides conclusive evidence that this disease is primarily a biological phenomenon rather than the result of abiotic factors.

Numerous soilborne organisms have been implicated as potential causal agents of apple replant disease. Plant-parasitic nematodes of the genus Pratylenchus were reported to have a major role in apple replant disease in the eastern United States $(11,14)$ and may have a role in the etiology of this disease in British Columbia (29) and Australia (7). Actinomycetes (30) and fluorescent pseudomonads (3) have been implicated as potential causal agents of apple replant disease. A number of soil fungi including Pythium spp. (12,22), Cylindrocarpon spp. (1,2,12), Phytophthora spp. (26), Armillaria mellea (26), Peniophora sacrata (27), Trichoderma hamatum, Torulomyces lagena, and Motierella sp. (29) have been associated with the occurrence of apple replant disease.

Due to its uncertain etiology, the control of apple replant disease has primarily been dependent upon the use of biologically broadspectrum soil sterilants such as methyl bromide or chloropicrin (14). While fumigants can provide effective control of replant diseases, there are several disadvantages inherent to the use of these broadspectrum biocides including difficulty in application, high cost, and potential hazards to human health. Further, since many fumigants are volatile pesticides, efficacy is dependent upon soil temperature and moisture. The development of selective chemical, cultural, or biological alternatives for the control of apple replant disease that approach the levels of disease control achieved with soil fumigants is, in large part, dependent upon a more complete understanding of the biology of this disease phenomenon. The objective of this 
study was to examine the soil microbial communities that are correlated with diminished growth of apple in replant soils and determine the role of specific microorganisms from various orchard soils in the development of this disease phenomenon.

\section{MATERIALS AND METHODS}

Orchard study sites. Soil and root samples were collected from the Washington State University/United States Department of Agriculture-Agricultural Research Station (USDA-ARS) Columbia View Experimental (CV) Orchard located 12 miles north of East Wenatchee, WA; a commercial orchard (DR) near Moxee, WA; a commercial orchard (KM) near Royal City, WA; a commercial orchard (GC) located near Manson, WA; and a research and demonstration orchard operated by Wenatchee Valley College (WVC) in Wenatchee, WA. The dominant soil types at the CV, DR, GC, KM, and WVC orchards are Burch sandy loam, Willis silt loam, Chelan gravelly sandy loam, Kennewick fine sandy loam, and Cowiche silt loam, respectively. The DR orchard was prepared for renovation in November 1994 by removal of trees and burning of the slash on site. In April 1995, the site was reestablished with five rows (6.1- by 2.4-m spacing) of the apple cultivar Gala on M26 rootstock, with four rows (rows B to E) planted directly into the rows of the previous orchard. The fifth row (row A) was established on the west edge of the block in soil that had not previously been planted to apple. The block was not fumigated prior to planting. By October 1995, the renovated block was exhibiting symptoms of replant disease, with $59 \%$ of trees in rows B to $\mathrm{E}$ either dead or in a severe state of decline, while trees in row A were healthy in appearance. At the CV orchard, samples were collected from a 7-year-old block of the cultivar Red Delicious on M111 rootstock. The GC orchard was established in 1991 on a site previously planted to apple and was not fumigated prior to replanting of 'Golden Delicious' on M26 rootstock. The KM orchard was established in 1995 on a site that had previously served as the orchard nursery. The site was not fumigated prior to the planting of 'Gala' on M9 rootstock. The WVC orchard site consisted of adjacent 1-acre blocks of 'Fuji' on M26 rootstock. Trees were removed in the autumn of 1996, at which time one block was fumigated with chloropicrin and the other block was left untreated prior to orchard establishment. The site was replanted to 'Gala' on M26 rootstock in May 1997.

Collection of soil and root samples. Soil and root samples used in this study were collected from all study sites during the last week of September and the first week of October 1996. Sample collection at the WVC orchard took place prior to orchard removal. Collection of soil in the early autumn of the year was intended to coincide with active growth of apple roots and enhanced microbial activity. Samples were also obtained at the GC orchard in April 1997, when nematode populations were expected to be near the lowest levels in their seasonal cycles (6). Additional sampling was conducted in specific orchards as indicated below. Composite soil samples were prepared by collecting soil within the root zone at a depth of 10 to $30 \mathrm{~cm}$ from a minimum of 15 sites within each orchard. Soil was placed in 16-liter sealed containers, transported to the Tree Fruit Research Laboratory in Wenatchee, WA, and stored until needed at $4^{\circ} \mathrm{C}$.

Growth conditions used in seedling assays. Except where noted, all assays that examined the effect of specific fungi on growth of apple, the effect of soil treatments on the growth of apple seedlings, and the effect of these soil treatments on the composition of microbial communities colonizing the rhizosphere of apple were conducted using similar growth conditions. Apple ('Gala') seeds were stratified and then sown in plastic flats containing sterile peat moss and perlite growth medium. Flats were placed in growth chambers at $24^{\circ} \mathrm{C}$. Treated and nontreated soil were dispensed into plastic tapered tubes $(26 \mathrm{~cm}$ long by $2.5 \mathrm{~cm}$ diameter; Ray Leach Cone-tainer, Canby, OR) with one 4-week-old seedling planted into each tube. Soil was covered with a $1-\mathrm{cm}$ layer of vermiculite, and $10 \mathrm{ml}$ of water was applied to each tube. Experiments were conducted using a randomized complete block design with seven seedlings per treatment for each of two replicates. Plants were placed in controlled environment chambers at $18^{\circ} \mathrm{C}$ with a $12-\mathrm{h}$ photoperiod $\left(95 \mu \mathrm{E} / \mathrm{m}^{2} / \mathrm{s}\right)$. At harvest, plant dry weights or the composition of specific microbial groups colonizing the seedling rhizosphere were determined as described below. All experiments were repeated at least once, except where noted.

Isolation, enumeration, and identification of plant-parasitic nematodes. Populations of plant-parasitic nematodes were determined for soil and root samples collected from the five study orchards and four additional commercial orchards; three located near Orondo, WA (JV, MD, and MM orchards), and one located near Quincy, WA (CW orchard). Root populations of Pratylenchus penetrans also were determined for apple seedlings grown in soil collected from the five study orchards, and the effect of soil treatments, described below, on lesion nematode populations in roots of apple transplants was assessed. Nematodes were extracted from four $50-\mathrm{cm}^{3}$ samples for each soil using a pie-pan modification of the Baermann funnel technique. Nematodes were extracted from roots of four trees for each orchard by placing $1.0 \mathrm{~g}$ of tissue into $80 \mathrm{ml}$ of water in 125-ml flasks and incubating on a Gyrotory shaker (model G2; New Brunswick Scientific Co., Inc., Melrose Park, IL) at $200 \mathrm{rpm}$ for $72 \mathrm{~h}$. Nematodes were collected by filtering the soil or root extract twice through a 500-mesh sieve and backwashing into a counting dish. Plant-parasitic nematodes were counted and identified using a dissecting microscope.

Isolation, enumeration, and identification of bacteria. The effect of soil pasteurization or the application of antibiotics, in studies described below, on populations of culturable bacteria in DR and GC orchard soils was assessed. Four soil samples were processed for each treated or nontreated soil. Soil suspensions were prepared by adding $0.5 \mathrm{~g}$ of soil to $10 \mathrm{ml}$ of sterile distilled water and vortexing for $60 \mathrm{~s}$. Serial dilutions of the suspension were plated onto one-tenth strength tryptic soy agar (TSA) (Difco Laboratories, Detroit); plates were incubated at $25^{\circ} \mathrm{C}$ and colonies were counted after $72 \mathrm{~h}$.

The composition of bacterial populations in the rhizosphere of apple seedlings grown in natural or pasteurized GC and DR orchard soils was determined. Four randomly selected seedlings from each soil were harvested and shaken to remove loosely adhering soil. Root tissue and firmly adhering soil $(0.4 \mathrm{~g})$ were placed in $10 \mathrm{ml}$ of sterile water, vortexed for $60 \mathrm{~s}$, and serial dilutions of the root wash were plated onto TSA. Twelve bacterial colonies were randomly selected for each root wash and identified by gas chromatographic fatty acid methyl esterase analysis using a Microbial Identification System equipped with an HP5890 series II gas chromatograph, HP 3365 Chem Station, and version 3.9 of the aerobe library (Microbial ID, Inc., Newark, DE). Preparation and analysis of samples were conducted according to the procedures recommended by the manufacturer. Similarity in bacterial species composition from the rhizosphere of apple seedlings grown in pasteurized or natural orchard soils were measured by the Ochiai index (similarity coefficient) and relative euclidean distance (RED) coefficient (13). Similarity coefficients vary from a minimum of 0 , when communities are completely different, to a maximum of 1 , when communities are identical. Conversely, distance coefficients assume a minimum value of 0 when the communities are identical and some maximum value when the communities are completely different.

Isolation, enumeration, and identification of fungi. With four rows planted into the old orchard site and an additional row planted into previously uncultivated soil, the DR orchard provided an opportunity to compare relative composition of fungal populations from healthy and diseased trees under the same soil and management conditions. Similarly, the WVC orchard possessed adjacent fumigated and nonfumigated blocks planted in May 1997 that were suitable for assessing differences in the composition of fungal pop- 
ulations from symptomatic and healthy apple trees. Roots were collected from the DR orchard on 9 November 1995 from 20 randomly selected trees in each health class, and from 44 trees in each health class at the WVC orchard on 2 July 1997. Replant disease primarily impacts the fibrous root system, leading to premature destruction of root hairs and diminished lateral root development $(4,9,20)$. Therefore, fungi were isolated from the fine root $(<0.3 \mathrm{~cm}$ in diameter) system of each tree by washing roots with tap water and plating 20 randomly selected segments ( 0.5 to $1.0 \mathrm{~cm}$ in length) on $1.5 \%$ water agar amended with ampicillin $(100 \mu \mathrm{g} / \mathrm{ml})$. After $72 \mathrm{~h}$ of incubation at 20 to $23^{\circ} \mathrm{C}$, root segments were examined using a light microscope (Olympus BH2 series; Olympus Optical Co., Ltd., Tokyo), and hyphae emanating from these tissues were transferred to fresh one-fifth potato dextrose agar (PDA) (Difco Laboratories). Sporulating fungi were identified at least to genus.

The fungal community from symptomatic root tissue of trees grown in replant soil was characterized. Root and soil samples were collected from 10 randomly selected symptomatic trees at the $\mathrm{CV}$, DR, GC, KM, and WVC orchards in September or October 1996. Fungi were isolated from 20 root segments that exhibited discoloration or bore distinct lesions for each tree and each of five seedlings grown in the respective orchard soils using the methods and plant growth conditions described above. Sporulating fungi were identified to genus. The composition of Rhizoctonia populations from the CV, DR, and WVC orchards previously were characterized (15). Identification of Rhizoctonia isolates from the GC orchard and those used in pathogenicity assays was conducted by first determining nuclear condition of the isolate (8) and then conducting anastomosis typing on $2 \%$ water agar (18) by pairing unknown isolates with isolates of known anastomosis grouping (15).

The effect of pasteurization treatments (described below) on populations of soil fungi and composition of the fungal community colonizing the roots of apple grown in GC orchard soil was determined. Soil suspensions were prepared for four separate soil samples as described above, and serial dilutions were plated onto onefifth PDA amended with ampicillin $(100 \mu \mathrm{g} / \mathrm{ml})$ and incubated at $25^{\circ} \mathrm{C}$; colonies were counted after $72 \mathrm{~h}$. Five apple seedlings were randomly selected for each soil treatment, roots were washed, 10 root segments $(0.5$ to $1.0 \mathrm{~cm}$ in length) from each seedling were plated onto $1.5 \%$ water agar amended with ampicillin $(100 \mu \mathrm{g} / \mathrm{ml})$, and fungi were identified as described above.

Suppression of soil microorganisms and effect on plant growth. Selective suppression of microbial populations was used as a means to define components of the soil microbiota that were most likely to have a role in apple replant disease. Suppression of specific soil microorganisms was achieved either by pasteurization of soil from the CV, GC, DR, and WVC orchards or the application of semiselective biocides to soil from all five study sites. Soil was pasteurized at $50,60,70$, or $95^{\circ} \mathrm{C}$ by exposing soil to a steamair mixture for $90 \mathrm{~min}$. All biocides were applied as an atomized

TABLE 1. Relative recovery of elements of the fungal complex associated with apple replant disease from lesions on roots of trees exhibiting disease symptoms and seedlings grown in soil from the respective study orchards

\begin{tabular}{lcrrrr}
\hline & \multicolumn{5}{c}{ Orchard $^{\mathrm{a}}$} \\
\cline { 2 - 5 } Fungal genus & $\mathrm{CV}$ & $\mathrm{DR}$ & $\mathrm{GC}$ & $\mathrm{KM}$ & WVC \\
\hline Cylindrocarpon & $34^{\mathrm{b}}$ & 9 & 27 & 2 & 20 \\
Fusarium & 2 & 8 & 14 & 7 & 3 \\
Phytophthora & 3 & 12 & 1 & 18 & 7 \\
Pythium & 6 & 22 & 2 & 23 & 41 \\
Rhizoctonia & 16 & 27 & 11 & 0 & 15 \\
\hline
\end{tabular}

a Orchard locations in Washington state: $\mathrm{CV}=\mathrm{E}$. Wenatchee, $\mathrm{DR}=$ Moxee, $\mathrm{GC}=$ Manson, $\mathrm{KM}=$ Royal City, and $\mathrm{WVC}=$ Wenatchee .

b Soil and root tissues were collected from each orchard in September or October 1996. Fungi were isolated from 20 root segments for each of five trees and each of five seedlings grown in the respective orchard soils. Values are the percentage of discolored or lesion bearing root segments from which fungi of a given genus were isolated. mist (16) with constant mixing of the soil during application to obtain uniform distribution of the chemical at the final concentration indicated. Nematode populations were specifically suppressed by application of the nematicide fenamiphos applied as Nemacur 3 $(0.146 \mu \mathrm{g}$ a.i. per $\mathrm{g}$ of soil). Fungicide treatments included the application of metalaxyl (Ridomil 2E) at 0.0026 and $0.0052 \mu \mathrm{g}$ a.i. per $\mathrm{g}$ of soil, benomyl (Benlate 50WP) at $0.052 \mu \mathrm{g}$ a.i. per $\mathrm{g}$ of soil, difenconazole (Dividend $250 \mathrm{EC}$ ) at 0.042 and $0.083 \mu \mathrm{g}$ a.i. per $g$ of soil, and metalaxyl $(0.0026 \mu \mathrm{g}$ a.i. per $\mathrm{g}$ of soil) with difenconazole $(0.083 \mu \mathrm{g}$ a.i. per $\mathrm{g}$ of soil). Fludioxinil (50 WP) was applied at $0.1 \mu \mathrm{g}$ a.i. per g soil to DR and GC orchard soils. Soil bacteria populations were selectively suppressed by application of kanamycin or streptomycin sulfate at a concentration of 40,60 , or $80 \mu \mathrm{g} / \mathrm{g}$ of soil or chloramphenicol at a concentration of $50 \mu \mathrm{g} / \mathrm{g}$ of soil. Soils were planted to 'Gala' apple seedlings that were grown in controlled environment chambers as described above. Plants were harvested after 5 weeks, and plant dry weights were determined.

Pathogenicity assays. A representative sample of fungi isolated from necrotic lesions and discolored segments of roots of apple grown in replant soils were assessed for pathogenicity toward apple. Assays were performed in natural Burch sandy loam collected from a noncultivated parcel within the CV orchard. Inoculum of each fungal isolate, with the exception of Phytophthora cactorum, was prepared by culturing in 500-ml Erlenmeyer flasks containing $250 \mathrm{ml}$ of oat bran and $80 \mathrm{ml}$ of distilled water. For Phytophthora cactorum, isolates were cultured in flasks containing $125 \mathrm{ml}$ of oat bran, $125 \mathrm{ml}$ of corn meal, and $90 \mathrm{ml}$ of distilled water. The flasks were sterilized on 2 consecutive days for $90 \mathrm{~min}$ and inoculated with a fungal culture growing on one-fifth PDA. Flasks were incubated at $20^{\circ} \mathrm{C}$ for 14 days, and inoculum was air-dried under a laminar flow hood. Inoculum was added to soil at a rate of $0.2 \%$ (wt/wt) and soils were incubated for $24 \mathrm{~h}$ at 20 to $23^{\circ} \mathrm{C}$ prior to planting. Plants were grown as described above, harvested after 4 weeks, and plant dry weights were determined.

Sensitivity of soil fungi to biocides. In vitro assays were conducted in an attempt to assess the relative activity of fungicides used in these studies towards fungi commonly isolated from the roots of trees expressing symptoms of replant disease in the field and from apple transplants grown in replant soils. Fungi assayed in these studies included $C$. destructans, Fusarium sambucinum, Trichoderma virens, Trichoderma viride, Phytophthora cactorum, Pythium ultimum, Pythium sylvaticum, and R. solani AG 5. A 5-mmdiameter plug was excised from the growing margin of a 5-day-old culture of each fungal isolate and placed in the center of a $100-\mathrm{mm}$ diameter petri plate containing one-fifth strength PDA or one-fifth

TABLE 2. Relative recovery of fungi from healthy apple trees and trees exhibiting symptoms of replant disease in the Moxee (DR) and Wenatchee (WVC) orchards in Washington state

\begin{tabular}{|c|c|c|c|c|}
\hline \multirow[b]{2}{*}{ Genus $^{a}$} & \multicolumn{2}{|c|}{ DR orchard $^{\text {b }}$} & \multicolumn{2}{|c|}{ WVC orchard ${ }^{\mathrm{b}}$} \\
\hline & Healthy & Diseased & Healthy & Diseased \\
\hline Alternaria & $65^{\mathrm{c}}$ & 35 & 82 & 18 \\
\hline Cylindrocarpon & 31 & 69 & 48 & 52 \\
\hline Fusarium & 57 & 43 & 79 & 21 \\
\hline Pythium & 14 & 86 & 23 & 77 \\
\hline Phytophthora & 0 & 100 & 0 & 100 \\
\hline Rhizoctonia & 4 & 96 & 20 & 80 \\
\hline Trichoderma & 42 & 58 & 77 & 23 \\
\hline
\end{tabular}

a The dominant species of the respective fungal genera were Alternaria alternata; Cylindrocarpon destructans; Fusarium sambucinum; Pythium ultimum and Pythium sylvaticum at the DR and WVC orchards, respectively; Phytophthora cactorum; Rhizoctonia solani AG 5; and Trichoderma virens.

b Trees were sampled on 9 November 1995 at the DR orchard and 2 July 1997 at the WVC orchard. Roots were collected from 20 individual trees in each health class at the DR orchard and 44 individual trees from each health class at the WVC orchard.

c Values are the percentage of the total number of isolates for a given fungal genus that were recovered from 20 root segments from each tree sampled for the two defined health classes. 
strength PDA amended with Nemacur $(5,10$, or $50 \mu \mathrm{g}$ a.i. per $\mathrm{ml})$, metalaxyl $(0.5,2$, or $8 \mu \mathrm{g}$ a.i. per $\mathrm{ml})$, benomyl $(0.5,1.0$, or $1.5 \mu \mathrm{g}$ a.i. per $\mathrm{ml})$, difenconazole $(1.25,5$, or $25 \mu \mathrm{g}$ a.i. per $\mathrm{ml})$, or fludioxinil $(10,20$, or $30 \mu \mathrm{g}$ a.i. per $\mathrm{ml})$ with three plates per isolate for each concentration. Radial growth was measured after $96 \mathrm{~h}$ of incubation at $20^{\circ} \mathrm{C}$. The experiment was repeated once.

Statistical analyses. Growth data were subjected to analysis of variance. If the $F$ test for treatments was significant, the least significant difference (LSD) test was applied to compare treatment means.

\section{RESULTS}

Populations of Pratylenchus penetrans in apple roots and orchard soils. Plant-parasitic nematodes isolated from soil collected at the surveyed orchards belonged primarily to the genera Paratylenchus, Pratylenchus, and Xiphenema. With the exception of Pratylenchus, soil populations of these plant-parasitic nematodes were low at all of the study orchards. Populations of Paratylenchus and Xiphenema did not exceed eight per $100 \mathrm{~cm}^{3}$ of soil (KM orchard) and three per $100 \mathrm{~cm}^{3}$ of soil (CV orchard), respectively. Soil populations of Pratylenchus penetrans did not exceed 25 per $100 \mathrm{~cm}^{3}$ of soil in eight of the nine orchards surveyed and were below 10 per $100 \mathrm{~cm}^{3}$ of soil in CV, CW, DR, KM, MD, MM, and WVC orchard soils. In contrast, the population of Pratylenchus penetrans in soil from the GC orchard averaged 176 per $100 \mathrm{~cm}^{3}$ of soil. Populations of Pratylenchus penetrans were below 10 per $\mathrm{g}$ of root at all sites, with the exception of the GC orchard, where populations averaged 565 per $\mathrm{g}$ of root for samples collected October 1996 and 134 per g of root for samples collected April 1997.

Fungi isolated from apple roots and orchard soils. The population of fungi isolated from apple root lesions typically consisted of a complex that included species of Cylindrocarpon, Fusarium, Pythium, Phytophthora, and Rhizoctonia. However, the relative dominance of individual species in the fungal community isolated from apple varied among the orchards, and some components of this complex were absent in specific orchards. For example, all components of the complex were isolated from roots of apple grown in CV, DR, GC, and WVC orchard soils (Table 1). In contrast, Pythium ultimum and Phytophthora cactorum dominated the fungal population recovered from symptomatic roots of apple grown in $\mathrm{KM}$ orchard soil. While all components were represented in the collection of fungi obtained from the roots of apple at the DR orchard, C. destructans, Fusarium spp., and R. solani AG 5 clearly dominated the fungal complex recovered from the GC orchard. In a previous study (15), the dominant species and anastomosis groups of Rhizoctonia were shown to vary among these orchards. The primary species of Pythium recovered from apple varied between sites, with Pythium ultimum dominating at the DR, CV, and KM orchards, while Pythium sylvaticum predominated at the WVC orchard. Isolates of Cylindrocarpon and Phytophthora recovered from symptomatic apple roots were consistently identified as $C$. destructans and Phytophthora cactorum, regardless of origin.

Seven genera including Alternaria, Cylindrocarpon, Fusarium, Phytophthora, Pythium, Rhizoctonia, and Trichoderma comprised greater than $95 \%$ of the fungal isolates recovered from the roots of healthy and symptomatic trees at the DR and WVC orchards. Isolates of Trichoderma and Cylindrocarpon spp. were isolated from trees regardless of health status (Table 2). Alternaria spp. were primarily recovered from the roots of apparently healthy trees, as were Fusarium spp., at the WVC orchard. In contrast, isolates of Pythium and Rhizoctonia were predominantly recovered from stunted trees or trees near death and were rarely present on the roots of healthy apple trees at this site. Isolates of Phytophthora were only recovered from the roots of symptomatic trees at both the DR and WVC orchards.

Sensitivity of soil fungi to biocides. Fungi commonly isolated from the roots of apple grown in replant soils exhibited varying levels of sensitivity toward the test biocides. Benomyl inhibited the growth of $C$. destructans, Fusarium spp., and Trichoderma at a concentration of $1.5 \mu \mathrm{g} / \mathrm{ml}$, but did not affect radial growth of Phytophthora cactorum, Pythium spp., or $R$. solani AG 5 (Table 3). As expected, growth of Phytophthora and Pythium spp. were suppressed by metalaxyl, though the concentration required to completely inhibit mycelial growth varied among isolates. Difenconazole completely inhibited growth of Trichoderma spp. and $C$. destructans at a concentration of 5.0 and $25 \mu \mathrm{g} / \mathrm{ml}$, respectively. Fusarium spp. were sensitive to difenconazole, with growth of one of two isolates completely inhibited at $25 \mu \mathrm{g} / \mathrm{ml}$, but growth of $R$. solani AG 5 appeared to be only moderately sensitive to this material. Isolates of Phytophthora and Pythium were insensitive to difenconazole. Growth of $R$. solani AG 5 was completely inhibited by fludioxinil at a concentration of $10 \mu \mathrm{g} / \mathrm{ml}$, and this fungicide showed moderate levels of activity toward $C$. destructans and Fusarium spp. All fungi evaluated in this study were insensitive to fenamiphos, with the exception of $R$. solani AG 5, which exhibited moderate growth inhibition at a concentration of $50 \mu \mathrm{g} / \mathrm{ml}$.

Effect of biocide applications on plant growth. Application of some semiselective biocides enhanced the growth of apple transplants in all five orchard soils tested. Likewise, pasteurization of orchard soils at $95^{\circ} \mathrm{C}$ increased plant biomass by 20 to $161 \%$ (Table 4). In those instances in which similar results were obtained for a specific orchard soil in two independent experiments, data

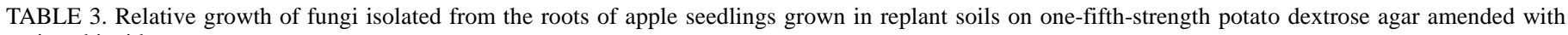
various biocides

\begin{tabular}{|c|c|c|c|c|c|c|c|c|c|c|c|c|c|c|c|}
\hline \multirow[b]{2}{*}{ Isolate $^{\mathrm{a}}$} & \multicolumn{15}{|c|}{ Biocide/concentration $(\mu \mathrm{g} \text { a.i. per } \mathrm{ml})^{\mathrm{b}}$} \\
\hline & ben/0.5 & ben $/ 1.0$ & ben $/ 1.5$ & $\mathrm{dif} / 1.25$ & $\mathrm{dif} / 5.0$ & $\mathrm{dif} / 25$ & $\mathrm{met} / 0.5$ & $\mathrm{met} / 2.0$ & met/10 & fen/5 & fen/10 & fen/50 & flu/10 & flu/20 & $\mathrm{flu} / 30$ \\
\hline C. destructans 8-13-11 & $0.82^{c}$ & 0.41 & 0.18 & 0.23 & 0.12 & 0 & 0.94 & 1.0 & 1.0 & 1.0 & 1.0 & 0.88 & 0.18 & 0.18 & 0.23 \\
\hline C. destructans D7-4 & 0.87 & 0.67 & 0 & 0.33 & 0.13 & 0 & 1.0 & 1.0 & 1.0 & 1.0 & 0.93 & 1.07 & 0.60 & 0.27 & 0.27 \\
\hline F. sambucinum E28-6 & 1.0 & 0.60 & 0.05 & 0.35 & 0.20 & 0.15 & 1.15 & 1.10 & 1.0 & 1.0 & 1.0 & 1.0 & 0.85 & 0.35 & 0.35 \\
\hline F. sambucinum WVC 9 & 0.93 & 0.43 & 0.10 & 0.16 & 0.07 & 0 & 0.97 & 0.90 & 1.0 & 1.0 & 0.97 & 0.80 & 0.67 & 0.50 & 0.50 \\
\hline P. cactorum A19-1 & 1.0 & 1.09 & 1.09 & 1.0 & 0.82 & 0.77 & 0 & 0 & 0 & 1.09 & 1.0 & 0.91 & 1.0 & 1.0 & 1.0 \\
\hline P. cactorum Downs2 & 1.21 & 0.86 & 0.86 & 1.0 & 0.96 & 0.88 & 0 & 0 & 0 & 1.27 & 1.14 & 1.14 & 1 & 0.93 & 0.71 \\
\hline P. ultimum $\mathrm{A} 30-2$ & 1.0 & 1.0 & 1.0 & 1.0 & 1.0 & 1.0 & 0.41 & 0.11 & 0 & 1.0 & 1.0 & 1.0 & 1.0 & 1.0 & 1.0 \\
\hline P. ultimum E41-4 & 1.0 & 1.0 & 1.0 & 1.0 & 0.94 & 0.82 & 0.08 & 0 & 0 & 1.0 & 1.0 & 1.0 & 0.77 & 0.62 & 0.59 \\
\hline R. solani AG 5 B32-1 & 1.04 & 1.0 & 1.0 & 0.72 & 0.69 & 0.58 & 1.0 & 0.92 & 0.92 & 0.92 & 0.92 & 0.77 & 0 & 0 & 0 \\
\hline R. solani AG 5 5-103 & 1.0 & 1.0 & 1.0 & 0.75 & 0.56 & 0.31 & 1.0 & 1.0 & 0.77 & 0.81 & 0.81 & 0.65 & 0 & 0 & 0 \\
\hline T. virens $\mathrm{MM} 2$ & 0.10 & 0 & 0 & 0 & 0 & 0 & 1.03 & 1.0 & 0.96 & 0.97 & 0.97 & 0.90 & 0.79 & 0.68 & 0.72 \\
\hline T. viride MM1 & 0.17 & 0.09 & 0.03 & 0.06 & 0 & 0 & 1.03 & 1.03 & 1.0 & 0.97 & 1.0 & 0.97 & 0.63 & 0.47 & 0.56 \\
\hline
\end{tabular}

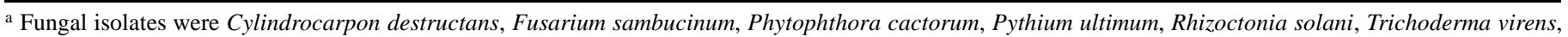
and Trichoderma viride.

${ }^{\mathrm{b}}$ ben $=$ benomyl, dif = difenconazole, fen = fenamiphos, flu = fludioxinil, and met = metalaxyl.

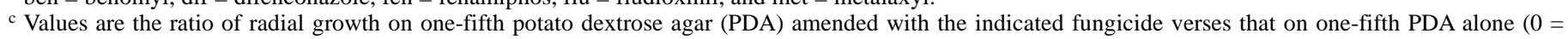
complete inhibition; $1.0=$ no inhibition). Values are the means of two experiments with three observations in each experiment. 
were pooled and analyzed. Data from individual experiments are reported in instances in which soils from the same orchard were collected on different dates or when additional biocide treatments were included based on results from initial studies.

Application of fenamiphos effectively eliminated plant-parasitic nematodes from all orchard soils, and populations of Pratylenchus penetrans did not exceed eight per $\mathrm{g}$ of root for seedlings grown in these treated soils. However, with the exception of GC orchard soil, no significant improvement in plant growth was observed in response to application of this nematicide. Enhanced growth of apple seedlings in GC orchard soil collected in October 1996 was observed in response to application of fenamiphos, but not in soil collected from the same orchard in April 1997. Application of the fungicide benomyl improved growth of apple only in replant soil from the GC orchard in two of three experiments. Application of metalaxyl enhanced growth of apple in all soils, except that from the WVC orchard, in at least one experiment, and difenconazole treatments also improved apple growth in four of five orchard soils in at least one experiment. The higher rate of metalaxyl and difenconazole did not significantly enhance the growth of apple relative to that achieved in soils treated with the lower rates of these fungicides. Growth of apple in KM orchard soil treated with the low rate of difenconazole was not significantly different from that obtained in untreated soil, but plant growth in soil treated with the high rate of difenconazole was significantly reduced and all seedlings were dead at harvest. Coapplication of difenconazole with metalaxyl effectively eliminated the seedling death observed in $\mathrm{KM}$ orchard soil treated with difenconazole alone. Application of fludioxinil improved growth of apple in the two orchard soils treated with this fungicide in at least one experiment.

Application of the antibiotics kanamycin sulfate or streptomycin sulfate did not significantly reduce populations of culturable bacteria in any orchard soil and did not affect the growth of apple in these soils. Although chloramphenicol applications reduced populations of culturable bacteria by a minimum of two orders of magnitude, no significant impact on growth of apple was observed in any of the orchard soils (data not shown).

Effect of pasteurization on plant growth and microbial populations. Soils were pasteurized at $50,60,70$, or $95^{\circ} \mathrm{C}$ prior to planting. Enhanced growth of apple transplants was observed in all four replant soils tested in response to soil pasteurization at $50^{\circ} \mathrm{C}$ (Table 5). With the exception of DR orchard soil, growth of apple transplants in replant soils pasteurized at $50^{\circ} \mathrm{C}$ was equivalent to that obtained in soils pasteurized at 60,70 , or $95^{\circ} \mathrm{C}$.
Total populations of culturable bacteria in soil from the DR and GC orchards were $4.6 \times 10^{6}$ and $8.6 \times 10^{6} \mathrm{CFU} / \mathrm{g}$ of soil, respectively, prior to pasteurization. Populations of culturable bacteria were not significantly affected by exposure of soil to a temperature of up to $70^{\circ} \mathrm{C}$, but bacterial populations in soil pasteurized at $95^{\circ} \mathrm{C}$ were below the limit of detection $\left(10^{3} \mathrm{CFU} / \mathrm{g}\right.$ of soil $)$ prior to planting. The species composition of culturable bacteria recovered from the rhizosphere of apple grown in natural soil and soil pasteurized at $50^{\circ} \mathrm{C}$ was highly similar (Tables 6 and 7), with an Ochiai index of 0.89 and 0.67 and RED of 0.11 and 0.17 for the DR and GC soils, respectively. Based on the Ochiai similarity index and RED coefficient, the bacterial communities from the rhizosphere of apple planted in natural soil and soil pasteurized at $50^{\circ} \mathrm{C}$ were more similar to each other than to the rhizosphere bacterial communities from soils pasteurized at any other temperature (Ochiai index ranging from 0.26 to 0.59 and RED ranging from 0.24 to 0.46 ).

Total populations of fungi were approximately $10^{6} \mathrm{CFU} / \mathrm{g}$ in both the DR and GC orchard soils. Pasteurization at $50^{\circ} \mathrm{C}$ resulted in a 10-fold reduction in fungal populations, and prior-to-planting populations were below the limit of detection $\left(10^{2} \mathrm{CFU} / \mathrm{g}\right.$ of soil) in soil pasteurized at 70 or $95^{\circ} \mathrm{C}$. Cylindrocarpon, Fusarium, Pythium, Rhizoctonia, and Trichoderma were the most common genera of fungi recovered from the roots of apple transplants grown in GC orchard soil. Cylindrocarpon and Fusarium spp. were recovered from 48 and $46 \%$, respectively, of root segments from seedlings grown in natural GC soil, but from less than $5 \%$ of root segments from seedlings grown in soil pasteurized at $50^{\circ} \mathrm{C}$. Pythium and Rhizoctonia spp. were not isolated from seedlings grown in pasteurized soil. Species of Trichoderma dominated the fungal population recovered from the roots of apple grown in pasteurized soil and were isolated from greater than $70 \%$ of apple root segments, regardless of pasteurization temperature.

Root populations of Pratylenchus penetrans from seedlings grown in natural GC soil averaged 342 per g of root, but were less than 10 per $g$ of root for seedlings grown in pasteurized soil, regardless of pasteurization temperature.

Pathogenicity of fungi associated with apple replant disease. The pathogenicity of fungi commonly isolated from the roots of apple transplants grown in orchard replant soils were evaluated in plant bioassays. Isolates of $C$. destructans, Phytophthora cactorum, Pythium ultimum, Pythium sylvaticum, and $R$. solani AG 5 caused extensive root rot of apple transplants and significant reductions in plant biomass (Table 8). In the same experiments, isolates of Fusarium were not pathogenic or were only weakly virulent

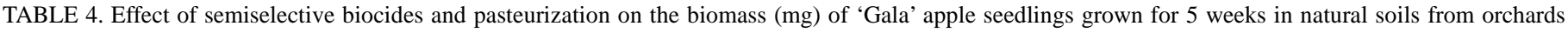
exhibiting symptoms of apple replant disease

\begin{tabular}{|c|c|c|c|c|c|c|c|c|}
\hline \multirow[b]{2}{*}{ Treatment $^{\mathrm{a}}$} & \multicolumn{8}{|c|}{ Orchard $^{\mathrm{b}}$} \\
\hline & $\mathrm{CV}$ & DR-1 & DR-2 & $\mathrm{GC}-1$ & GC-2 & GC-3 & KM & WVC \\
\hline Control & $626^{c}$ & 549 & 633 & 661 & 249 & 504 & 435 & 495 \\
\hline Benomyl & 611 & 470 & 649 & 971 & 279 & 641 & 402 & 541 \\
\hline Fenamiphos & 635 & 548 & 673 & 872 & 507 & 544 & 388 & 528 \\
\hline Difenconazole- $\mathrm{L}^{\mathrm{d}}$ & 736 & 712 & 717 & 792 & 464 & 542 & 378 & 648 \\
\hline Difenconazole-H & 739 & 775 & 667 & 901 & 541 & 511 & 57 & 623 \\
\hline Metalaxyl-L & 722 & 734 & 687 & 913 & 496 & 557 & 558 & 552 \\
\hline Metalaxyl-H & 743 & 752 & 699 & 854 & 515 & 548 & 507 & 536 \\
\hline Difenconazole + metalaxyl & 716 & 785 & 759 & 1,031 & 566 & 622 & 438 & 621 \\
\hline Fludioxinil & $\ldots e^{e}$ & $\ldots$ & 796 & 798 & 438 & 567 & $\ldots$ & $\ldots$ \\
\hline Fenamiphos + fludioxinil & $\ldots$ & $\ldots$ & $\ldots$ & 902 & 472 & 660 & $\ldots$ & $\ldots$ \\
\hline $70^{\circ} \mathrm{C}$ pasteurization & 731 & 720 & 828 & 1,213 & 601 & 729 & 572 & 629 \\
\hline $95^{\circ} \mathrm{C}$ pasteurization & 753 & 794 & 739 & 1,275 & 653 & 768 & 546 & 660 \\
\hline $\operatorname{LSD}(P=0.05)$ & 70 & 91 & 69 & 127 & 84 & 101 & 104 & 113 \\
\hline
\end{tabular}

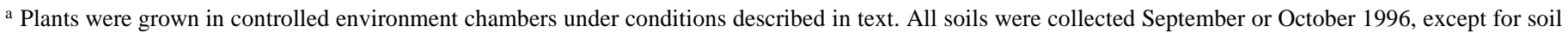
used in experiment GC-3, which was collected April 1997.

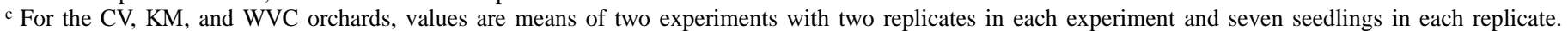

Where orchard abbreviations are followed by a number, values are means of an individual experiment.

d Difenconazole and metalaxyl were applied at a low $(\mathrm{L})$ or high $(\mathrm{H})$ rate as indicated in text.

e Treatment was not included in the experiment. 
toward apple transplants. Assays were conducted to examine the virulence of additional isolates of Fusarium toward apple and the possibility that Fusarium spp. acted synergistically to exacerbate disease symptoms caused by other fungi isolated from replant soils. Among 19 isolates of Fusarium from multiple replant sites, only F. sambucinum $\mathrm{H} 7-1$ significantly reduced the biomass of 6-weekold 'Gala' apple seedlings when grown for 6 weeks in controlled environment chambers (Table 9). Isolates 7571, 7573, D8-A, and Q20-C each induced distinct lesions on apple roots, but plants grown in soil infested with these isolates did not exhibit significant reductions in growth. In the same assay, the biomass of seedlings grown in soil infested with $R$. solani AG 5 5-103 was significantly reduced relative to seedlings grown in noninfested soil. The dry weight of apple transplants grown in soil infested individually with Pythium ultimum A30-2 or $R$. solani AG 5 5-103 did not differ significantly from that obtained in soil infested with the respective pathogens in combination with $F$. solani D44-1 (Table 10). A similar result was obtained when $C$. destructans 8-13-11 was used in coinoculations with these isolates of $R$. solani and Pythium ultimum. Plant biomass of seedlings grown in soil coinfested with Pythium ultimum and $C$. destructans was significantly less than that of seedlings grown in soil coinfested with Pythium ultimum and $F$. solani.

TABLE 5. Biomass ( $\mathrm{mg}$ ) of 'Gala' apple seedlings after 5 weeks of growth in natural or pasteurized replant orchard soils

\begin{tabular}{lllrc}
\hline & \multicolumn{4}{c}{ Orchard $^{\mathrm{a}}$} \\
\cline { 2 - 5 } Temperature $\left({ }^{\circ} \mathrm{C}\right)$ & $\mathrm{CV}$ & $\mathrm{DR}$ & $\mathrm{GC}$ & WVC \\
\hline Control & $576^{\mathrm{b}}$ & 726 & 463 & 566 \\
50 & 865 & 829 & 1,018 & 729 \\
60 & 884 & 858 & 975 & 736 \\
70 & 834 & 929 & 897 & 780 \\
95 & 942 & 954 & 933 & 691 \\
LSD $(P=0.05)$ & 161 & 91 & 238 & 102 \\
\hline
\end{tabular}

${ }^{a}$ Orchard locations in Washington state: $\mathrm{CV}=\mathrm{E}$. Wenatchee, $\mathrm{DR}=$ Moxee, $\mathrm{GC}=$ Manson, and WVC = Wenatchee.

b Values are means of two experiments with two replicates in each experiment and seven seedlings in each replicate.

TABLE 6. Relative populations of bacteria recovered from the rhizosphere of apple transplants grown in natural or pasteurized Willis silt loam from the DR orchard near Moxee, WA

\begin{tabular}{lccccc}
\hline & \multicolumn{5}{c}{ Pasteurization temperature } \\
\cline { 2 - 6 } Bacterial species & Control & $50^{\circ} \mathrm{C}$ & $60^{\circ} \mathrm{C}$ & $70^{\circ} \mathrm{C}$ & $95^{\circ} \mathrm{C}$ \\
\hline Agrobacterium tumefaciens & $\ldots$ & $\ldots$ & $\ldots$ & 2.1 & $\ldots$ \\
Alcaligenes piechaudii & $\ldots$ & $\ldots$ & $\ldots$ & $\ldots$ & 2.1 \\
Arthrobacter oxydans & 8.3 & 4.2 & $\ldots$ & $\ldots$ & $\ldots$ \\
Bacillus chitinosporus & 4.2 & $\ldots$ & $\ldots$ & $\ldots$ & $\ldots$ \\
Bacillus laterosporus & 8.3 & 8.3 & 8.3 & $\ldots$ & 4.2 \\
Bacillus megaterium & $\ldots$ & $\ldots$ & $\ldots$ & 4.2 & $\ldots$ \\
Bacillus mycoides & 2.1 & 4.2 & 4.2 & $\ldots$ & $\ldots$ \\
Burkholderia cepacia & 14.6 & 16.7 & 25.0 & 8.3 & $\ldots$ \\
Cytophaga johnsonae & 16.7 & 16.7 & $\ldots$ & 8.3 & 18.8 \\
Enterobacter intermedius & $\ldots$ & 4.2 & $\ldots$ & $\ldots$ & 10.4 \\
Flavobacterium resinovorum & 4.2 & 8.3 & 27.1 & 8.3 & 12.5 \\
Hydrogenophaga pseudoflava & $\ldots$ & $\ldots$ & 2.1 & 12.5 & $\ldots$ \\
Micrococcus luteus & $\ldots$ & $\ldots$ & 4.2 & 2.1 & $\ldots$ \\
Pseudomonas chlororaphis & $\ldots$ & $\ldots$ & $\ldots$ & 6.3 & $\ldots$ \\
Pseudomonas fluorescens & $\ldots$ & $\ldots$ & $\ldots$ & 4.2 & 18.8 \\
Pseudomonas putida & 16.7 & 22.9 & $\ldots$ & 12.5 & 16.7 \\
Sphingobacterium spiritivorum & $\ldots$ & $\ldots$ & $\ldots$ & 6.3 & 4.2 \\
Sphingomonas capulata & $\ldots$ & $\ldots$ & 8.3 & $\ldots$ & $\ldots$ \\
Stenotrophomonas maltophilia & 6.3 & 2.1 & $\ldots$ & $\ldots$ & $\ldots$ \\
Not identified & & $\ldots$ & $\ldots$ & $\ldots$ \\
Total culturable bacteria & 18.8 & 12.5 & 20.1 & 25.0 & 12.5 \\
(CFU/g of soil) & & & & & \\
\hline a & $4.6 \times 10^{6}$ & $8.1 \times 10^{6}$ & $1.2 \times 10^{7}$ & $2.2 \times 10^{6}$ & $\mathrm{ND}^{\mathrm{c}}$ \\
\hline
\end{tabular}

${ }^{a}$ Indicates that the organism was not present in the sample. Values are a percentage of the total number of bacterial isolates identified for a given soil.

${ }^{\mathrm{b}}$ Isolates were lost during subculturing or could not be identified with certainty by gas chromatographic fatty acid methyl esterase analysis.

${ }^{\mathrm{c}} \mathrm{ND}=$ not detected. Lower limit of detection was $10^{2} \mathrm{CFU} / \mathrm{g}$ of soil.

\section{DISCUSSION}

Without adequate knowledge of the primary causal agents, control of apple replant disease has continued to rely on the use of soil fumigants that possess a broad spectrum of antimicrobial activity. Although studied by numerous investigators across diverse geographic regions, considerable uncertainty exists concerning the dominant causal agent or agents of apple replant disease, even within a given region. The systematic examination of the etiology of apple replant disease conducted in this study utilized several approaches to define the causative agents of replant disease. These approaches included an analysis of the microbial community in the rhizosphere of symptomatic and healthy trees, determination of the impact of semiselective biocides and soil pasteurization on plant growth, assessment of the changes in composition of microbial communities on apple roots in response to soil pasteurization, and evaluation of the pathogenicity of microorganisms commonly isolated from apple root lesions in assays conducted in natural soil using plausible inoculum concentrations.

The results from these studies provide several lines of evidence that implicate plant-pathogenic fungi as the dominant causal agents of apple replant disease in Washington state. For instance, application of one or more of the test fungicides enhanced growth of apple in each of the five orchard soils and, typically, growth of apple seedlings in response to one or more of these materials was equivalent to that obtained in soil pasteurized at $95^{\circ} \mathrm{C}$. The enhanced growth of apple in response to soil pasteurization and the corresponding changes in the composition of fungal species isolated from the roots of apple also support the role of fungi in the etiology of this disease. Pasteurization of soil at $50^{\circ} \mathrm{C}$ enhanced growth of apple in all four orchard soils tested, and this corresponded with significant reductions in populations of soil fungi. In addition, dramatic changes in the fungal community isolated from seedlings

TABLE 7. Relative populations of bacteria recovered from the rhizosphere of apple transplants grown in natural or pasteurized Chelan gravelly sandy loam from the GC orchard near Manson, WA

\begin{tabular}{lccccc}
\hline & \multicolumn{5}{c}{ Pasteurization temperature } \\
\cline { 2 - 6 } Bacterial species & Natural & $50^{\circ} \mathrm{C}$ & $60^{\circ} \mathrm{C}$ & $70^{\circ} \mathrm{C}$ & $95^{\circ} \mathrm{C}$ \\
\hline Agrobacterium tumefaciens & $2.1^{\mathrm{a}}$ & $\ldots$ & $\ldots$ & $\ldots$ & $\ldots$ \\
Arthrobacter globiformis & $\ldots$ & $\ldots$ & $\ldots$ & $\ldots$ & 4.2 \\
Arthrobacter ramosus & $\ldots$ & 4.2 & 4.2 & $\ldots$ & $\ldots$ \\
Bacillus cereus & 4.2 & $\ldots$ & $\ldots$ & $\ldots$ & $\ldots$ \\
Bacillus laterosporus & $\ldots$ & 8.3 & $\ldots$ & 20.8 & $\ldots$ \\
Bacillus megaterium & 4.2 & 4.2 & $\ldots$ & $\ldots$ & $\ldots$ \\
Bacillus thuringiensis & $\ldots$ & 2.1 & $\ldots$ & $\ldots$ & $\ldots$ \\
Burkholderia cepacia & 4.2 & 4.2 & 20.8 & 10.4 & 4.2 \\
Chryseobacterium indologenes & $\ldots$ & 8.3 & $\ldots$ & $\ldots$ & $\ldots$ \\
Curtobacterium flaccumfaciens & $\ldots$ & $\ldots$ & $\ldots$ & $\ldots$ & 2.1 \\
Cytophaga jonhsonae & 16.7 & 10.4 & $\ldots$ & $\ldots$ & 4.2 \\
Enterobacter amnigenus & $\ldots$ & $\ldots$ & $\ldots$ & $\ldots$ & 12.5 \\
Enterobacter intermedius & $\ldots$ & $\ldots$ & $\ldots$ & $\ldots$ & 4.2 \\
Flavobacterium resinovorum & 12.5 & 14.6 & 8.3 & $\ldots$ & 6.3 \\
Micrococcus lylae & $\ldots$ & $\ldots$ & $\ldots$ & 4.2 & $\ldots$ \\
Pseudomonas chlororaphis & $\ldots$ & $\ldots$ & 4.2 & $\ldots$ & $\ldots$ \\
Pseudomonas fluorescens & 16.7 & 16.7 & 16.7 & 12.5 & 14.6 \\
Pseudomonas putida & 20.8 & 22.9 & 29.2 & 18.8 & 10.4 \\
Rhodococcus erythropolis & $\ldots$ & $\ldots$ & $\ldots$ & 6.3 & 4.2 \\
Salmonella typhimurium & $\ldots$ & $\ldots$ & $\ldots$ & $\ldots$ & 4.2 \\
Sphingomonas capsulata & 12.5 & 4.2 & $\ldots$ & 4.2 & 8.3 \\
Stentrophomonas maltophilia & 4.2 & $\ldots$ & 2.1 & $\ldots$ & $\ldots$ \\
Xenorhabdus nematophilus & $\ldots$ & $\ldots$ & $\ldots$ & 4.2 & 4.2 \\
No identification & $\ldots$ & $\ldots$ & 14.6 & 18.8 & 16.7 \\
Total culturable bacteria & 2.1 & $\ldots$ & & \\
(CFU/g of soil) & $8.6 \times 10^{6}$ & $7.4 \times 10^{6}$ & $6.8 \times 10^{6}$ & $1.2 \times 10^{6}$ & $\mathrm{ND}$ \\
\hline - & & & \\
\hline
\end{tabular}

a Values are a percentage of the total number of bacterial isolates identified for a given soil.

$\mathrm{b}$ Indicates that the organism was not present in the sample.

${ }^{\mathrm{c}}$ Isolates were lost during subculturing or could not be identified with cer-

tainty by gas chromatographic fatty acid methyl esterase analysis.

${ }^{\mathrm{d}} \mathrm{ND}=$ not detected. Lower limit of detection was $10^{2} \mathrm{CFU} / \mathrm{g}$ of soil. 
grown in these soils were observed in response to pasteurization temperatures that enhanced plant growth. In natural GC orchard soil, species of Cylindrocarpon, Fusarium, and Rhizoctonia comprised the majority of isolates recovered from apple roots, while Trichoderma spp. clearly dominated the fungal population from the roots of apple grown in soil pasteurized at $50^{\circ} \mathrm{C}$ or higher.

Although numerous species of fungi have been implicated in the etiology of apple replant disease $(1,2,7,12,22,26,27,29)$, there have been only limited attempts to elucidate the role of these organisms over multiple sites, and there is no consensus as to the relative importance of these fungi outside of a given orchard. Fungi that have most commonly been associated with apple replant disease include species of Cylindrocarpon $(1,2,7,12)$ and Pythium $(1,2,7,12,22)$. The fungal complex that was routinely associated with replant disease of apple at the orchards surveyed in this study included $C$. destructans, Fusarium spp., Pythium ultimum, Pythium sylvaticum, Phytophthora cactorum, and $R$. solani. With the exception of isolates of Fusarium, each of these fungi appear to have a significant role in the etiology of replant disease of apple in Washington. In pathogenicity assays conducted in natural soil, these fungi caused root rot of apple and significantly reduced plant biomass. In addition, application of semiselective biocides that specifically suppressed these fungi enhanced the growth of apple seedlings in soil from orchards that exhibited symptoms of replant disease. The causative role of $C$. destructans, Pythium spp., and Phytophthora cactorum is in agreement with other studies that have proposed a role for these fungi as a component of a disease complex inciting apple replant disease, and this study substantiates the role of $R$. solani in disease development.

Fusarium spp. were commonly recovered from roots of apple grown in soils from these same orchards; however, the majority of Fusarium isolates evaluated in pathogenicity assays had only a marginal impact or no effect on growth of apple transplants. In addition, at a block within the WVC orchard replanted in May 1997, Fusarium spp. accounted for more than $30 \%$ of fungal isolates recovered from the roots of apparently healthy apple trees ('Gala' on M26 rootstock) grown in soil fumigated prior to planting, but only $6 \%$ of those recovered from trees planted in the adjacent nonfumigated block that were exhibiting symptoms of apple replant disease. These data indicate that, in contrast to other regions (7), Fusarium spp. do not have a major causal role in the replant problem observed in Washington state.

TABLE 8. Biomass of 'Gala' apple seedlings after 4 weeks of growth in natural Burch sandy loam amended with fungi isolated from trees exhibiting symptoms of apple replant disease

\begin{tabular}{|c|c|c|}
\hline Fungal isolate ${ }^{a}$ & Orchard of origin ${ }^{b}$ & Plant wt (mg) \\
\hline Control & & $986^{\mathrm{c}}$ \\
\hline Cylindrocarpon destructans 8-13-11 & $\mathrm{CV}$ & 698 \\
\hline Cylindrocarpon destructans 7-5-9 & $\mathrm{CV}$ & 564 \\
\hline Cylindrocarpon destructans D7-4 & WVC & 637 \\
\hline Fusarium solani D44-1 & DR & 838 \\
\hline Fusarium sambucinum E28-6 & DR & 850 \\
\hline Fusarium merismoides Q20-3 & $\mathrm{GC}$ & 784 \\
\hline Fusarium sambucinum WVC-9 & WVC & 746 \\
\hline Phytophthora cactorum A19-2 & DR & 554 \\
\hline Phytophthora cactorum D7-2 & DR & 644 \\
\hline Phytophthora cactorum Downs2 & MD & 581 \\
\hline Pythium sylvaticum B37-1 & DR & 557 \\
\hline Pythium ultimum A30-2 & DR & 631 \\
\hline Pythium ultimum 6-113 & $\mathrm{CV}$ & 572 \\
\hline Rhizoctonia solani AG 5 5-103 & DR & 632 \\
\hline Rhizoctonia solani AG 5 CV-G & $\mathrm{CV}$ & 393 \\
\hline Rhizoctonia solani AG 5 B32-1 & DR & 578 \\
\hline $\operatorname{LSD}(P=0.05)$ & & 219 \\
\hline
\end{tabular}

${ }^{a}$ Fungal inoculum was prepared and introduced into soil, and plants were grown in controlled environment chambers as described in text.

b Orchard locations in Washington state: $C V=E$. Wenatchee, $D R=$ Moxee, $\mathrm{GC}=$ Manson, $\mathrm{MD}=$ Orondo, and $\mathrm{WVC}=$ Wenatchee .

$c$ Values are means of two experiments with two replicates in each experiment and seven seedlings in each replicate.
The primary factors that contribute to apple replant disease have been reported to vary significantly among regions and even among orchards within the same region $(7,14)$. A surprising level of consistency was observed in the composition of the microbial complex that contributed to apple replant disease at the sites surveyed in this study, though the relative contribution of these elements to the disease phenomenon varied between orchards. While $C$. destructans and R. solani dominated at the GC orchard, Pythium ultimum and Phytophthora cactorum were the primary causal agents of replant disease at the KM orchard. At the DR, CV, and WVC orchards, isolates of $C$. destructans, Pythium spp., Phytophthora cactorum, and $R$. solani all appeared to have a role in disease development. As stated above, variation was observed in the composition of the Rhizoctonia (15) and Pythium components of this fungal complex among the replant sites.

Results from the assays conducted in KM orchard soil demonstrate a potential problem that could ensue should the dominant causal agent or agents be insufficiently characterized or control measures target only one component of the disease complex. Pythium ultimum and Phytophthora cactorum were the principal soilborne pathogens of apple at this site. Application of difenconazole to KM orchard soil resulted in reduced growth and mortality of apple seedlings. Apparent antagonistic relationships have been reported to exist between pathogens, including $R$. solani and Pythium ultimum, that parasitize the same plant tissues $(19,32)$. Similar relationships appear to exist among these fungi in the rhizosphere of apple, as evidenced by the fact that application of fludioxinil at the WVC orchard effectively eliminated $R$. solani from apple roots, but resulted in a $93 \%$ increase in recovery of Pythium spp. from the same root tissues (M. Mazzola, unpublished data). Given the relative sensitivity of fungi examined in this study, it is likely that difenconazole eliminated elements of the fungal community, including species of Cylindrocarpon, Fusarium, Rhizoctonia, and Trichoderma, that directly compete with pythiaceous fungi for colonization sites in the rhizosphere of apple, thus enabling the resident population of Pythium and Phytophthora spp. to fill this

TABLE 9. Biomass of 'Gala' apple seedlings after 6 weeks of growth in natural Burch sandy loam amended with Rhizoctonia solani AG 5 or various isolates of Fusarium

\begin{tabular}{|c|c|c|}
\hline Fungal isolate $^{\mathrm{a}}$ & Orchard of origin & Plant wt (g) \\
\hline Control & & $1.99^{\mathrm{b}}$ \\
\hline R. solani AG 5 5-103 & $\mathrm{CV}^{\mathrm{c}}$ & 1.45 \\
\hline Fusarium sp. 7571 & $\mathrm{CV}$ & 2.02 \\
\hline F. merismoides 7573 & $\mathrm{CV}$ & 1.82 \\
\hline Fusarium sp. 7842 & $\mathrm{CV}$ & 1.97 \\
\hline F. lateritium 8.11.4.1 & $\mathrm{CV}$ & 1.98 \\
\hline Fusarium sp. 8.13.11.1 & $\mathrm{CV}$ & 2.17 \\
\hline F. sambucinum 14-278 & WVC & 1.84 \\
\hline F. sambucinum A19-1 & DR & 1.83 \\
\hline F. chlamydosporum A30-1 & DR & 2.00 \\
\hline F. solani $\mathrm{C} 17-1$ & DR & 1.87 \\
\hline Fusarium sp. D5-3 & DR & 2.03 \\
\hline F. merismoides D8-A & $\mathrm{GC}$ & 1.97 \\
\hline F. sambucinum E28-6 & DR & 2.01 \\
\hline Fusarium sp. H3-2 & DR & 1.95 \\
\hline F. sambucinum $\mathrm{H} 4-2$ & DR & 2.01 \\
\hline Fusarium sp. H6-1 & DR & 1.93 \\
\hline F. sambucinum $\mathrm{H} 7-1$ & DR & 1.60 \\
\hline F. merismoides Q20-C & GC & 1.83 \\
\hline Fusarium sp. R13C & GC & 1.90 \\
\hline F. sambucinum WVC-9 & WVC & 1.92 \\
\hline $\operatorname{LSD}(P=0.05)$ & & 0.36 \\
\hline
\end{tabular}

${ }^{a}$ Fungal inoculum was prepared and introduced into soil as described in text. Soils were planted to 6-week-old 'Gala' apple seedlings and grown for an additional 6 weeks in controlled environment chambers at $18^{\circ} \mathrm{C}$ and a 12 -h photoperiod.

${ }^{b}$ Experiment was conducted once and values are means of two replicates with seven seedlings in each replicate.

c Orchard locations in Washington state: $\mathrm{CV}=\mathrm{E}$. Wenatchee, $\mathrm{DR}=$ Moxee, $\mathrm{GC}=$ Manson, and WVC $=$ Wenatchee. 
ecological void. The fact that seedling mortality was eliminated when metalaxyl, a material that specifically suppresses pythiaceous fungi, was applied in conjunction with difenconazole, supports this hypothesis.

Although Pythium spp. represented a significant portion of the fungal population recovered from the roots of symptomatic trees at the WVC orchard, soil application of metalaxyl failed to enhance growth of apple seedlings in soil from this orchard. Likewise, application of this fungicide as a soil drench failed to improve the growth of 'Gala' on M26 planted at this site in May 1997. Complete inhibition of in vitro growth was observed for 27 of 30 isolates of Pythium from the DR orchard, but only 1 of 39 isolates from the WVC orchard at a metalaxyl concentration of $1 \mu \mathrm{g} / \mathrm{ml}$ (M. Mazzola, unpublished data). Thus, it is plausible that the failure of metalaxyl treatments to promote the growth of apple in WVC orchard soil resulted from the presence of a Pythium spp. population that is insensitive to this fungicide.

These studies have documented that certain elements of the soil microbial community previously implicated in disease development in other regions may have only a limited or no role in the etiology of apple replant disease in central Washington. Bacteria including fluorescent pseudomonads and Bacillus subtilis have, on occasion, been reported to contribute to the development of apple replant disease $(3,29)$. In contrast, Dullahide et al. (7) concluded that bacteria isolated from apple roots were not pathogenic to apple and did not have a role in the disease phenomenon observed in the Granite Belt of Queensland, Australia. In the current study, soil treatments that specifically reduced bacterial populations in replant soils had no effect on the growth of apple. In addition, treatments that had no discernable effect on the composition of bacterial communities isolated from the roots of apple, such as soil pasteurization at $50^{\circ} \mathrm{C}$, consistently improved the growth of apple in soils from each of the orchards exhibiting symptoms of replant disease. These findings suggest that bacteria do not have a significant causal role in the etiology of apple replant disease in Washington.

Numerous investigators have concluded that the lesion nematode, Pratylenchus spp., has a causal role in apple replant disease $(7,11$, $17,25,29)$. However, the relative importance of this nematode in disease development appears to vary among geographic regions. Populations of plant-parasitic nematodes including Pratylenchus penetrans were not correlated with the incidence of symptomatic trees in Maine, and nematode counts in healthy orchard soils often exceeded those recovered from replant soils (4). Nematicidal concentrations of soil fumigants did not improve growth of apple in Washington and certain New York orchards in which soil pasteurization and chloropicrin provided disease control $(5,11)$. In the survey of orchards conducted in this study, populations of the lesion nematode did not exceed 25 per $100 \mathrm{~cm}^{3}$ of soil at eight of nine sites, a population below the minimum required to cause damage to apple (10). Covey et al. (5) also recovered low populations of Pratylenchus penetrans in five Washington orchards with histories

TABLE 10. Biomass of 'Gala' apple seedlings after 4 weeks of growth in natural Burch sandy loam amended with fungal isolates alone and in combination

\begin{tabular}{lc}
\hline${\text { Fungal isolate }(\mathrm{s})^{\mathrm{a}}}$ & Plant wt (mg) \\
\hline Control $_{\text {Cylindrocarpon destructans } 8-13-11}$ & $678^{\mathrm{b}}$ \\
Fusarium solani D44-1 & 441 \\
Pythium ultimum A30-2 & 577 \\
Pythium ultimum A30-2 + F. solani D44-1 & 238 \\
Pythium ultimum A30-2 + C. destructans 8-13-11 & 320 \\
Rhizoctonia solani AG 5 5-103 & 171 \\
Rhizoctonia solani AG 5 5-103 + F. solani D44-1 & 320 \\
Rhizoctonia solani AG 5 5-103 + C. destructans 8-13-11 & 367 \\
LSD $(P=0.05)$ & 268 \\
\hline
\end{tabular}

${ }^{a}$ Fungal inoculum was prepared and introduced into soil, and plants were grown in controlled environment chambers as described in text.

b Values are means of two experiments with two replicates in each experiment and seven seedlings in each replicate. of apple replant disease. Although application of fenamiphos effectively eliminated Pratylenchus penetrans, an increase in the biomass of apple seedlings in response to this nematicide was only observed in the coarse textured soil from the GC orchard, and only when soil was collected from this site in the fall of the year when nematode populations were highest. These results demonstrate that the lesion nematode typically has a minor role or no role in the etiology of apple replant disease in Washington.

The studies described here on the etiology of apple replant disease may provide the framework necessary to develop specific alternatives to preplant soil fumigation for the control of the disease in Washington. Control measures can now be formulated that target individual components of the disease complex. From these foundations, a comprehensive biologically based management system may be attainable that provides commercially viable levels of disease control.

\section{ACKNOWLEDGMENTS}

I thank E. L. Valdez and S. K. Ivanov for excellent technical assistance, and C. A. Lévesque and F. N. Martin for assistance in the identification of isolates of Pythium.

\section{LITERATURE CITED}

1. Braun, P. G. 1991. The combination of Cylindrocarpon lucidum and Pythium irregulare as a possible cause of apple replant disease in Nova Scotia. Can. J. Plant Pathol. 13:291-297.

2. Braun, P. G. 1995. Effects of Cylindrocarpon and Pythium species on apple seedlings and potential role in apple replant disease. Can. J. Plant Pathol. 17:336-341.

3. Bunt, J. A., and Mulder, D. 1973. The possible role of bacteria in relation to the apple replant disease. Meded. Fac. Landbouwwet. Rijksuniv. Gent. 38:1381-1385.

4. Caruso, F. L., Neubauer, B. F., and Begin, M. D. 1989. A histological study of apple roots affected by replant disease. Can. J. Bot. 67:742-749.

5. Covey, R. P., Jr., Benson, N. R., and Haglund, W. A. 1979. Effect of soil fumigation on the apple replant disease in Washington. Phytopathology 69:684-686.

6. Dropkin, V. H. 1980. Introduction to Plant Nematology. John Wiley \& Sons, New York.

7. Dullahide, S. R., Stirling, G. R., Nikulin, A., and Stirling, A. M. 1994. The role of nematodes, fungi, bacteria, and abiotic factors in the etiology of apple replant problems in the Granite Belt of Queensland. Aust. J. Exp. Agric. 34:1177-1182.

8. Herr, L. J. 1979. Practical nuclear staining procedures for Rhizoctonialike fungi. Phytopathology 69:958-961.

9. Hoestra, H. 1968. Replant diseases of apple in the Netherlands. Ph.D. thesis. Meded. Landbouwhogesch. Wageningen, the Netherlands.

10. Hoestra, H., and Oostenbrink, M. 1962. Nematodes in relation to plant growth. IV. Pratylenchus penetrans on orchard trees. Neth. J. Agric. Sci. 10:286-296.

11. Jaffee, B. A., Abawi, G. S., and Mai, W. F. 1982. Role of soil microflora and Pratylenchus penetrans in an apple replant disease. Phytopathology 72:247-251.

12. Jaffee, B. A., Abawi, G. S., and Mai, W. F. 1982. Fungi associated with roots of apple seedlings grown in soil from an apple replant site. Plant Dis. 66:942-944.

13. Ludwig, J. A., and Reynolds, J. F. 1988. Statistical Ecology: A Primer on Methods and Computing. John Wiley \& Sons, New York.

14. Mai, W. F., and Abawi, G. S. 1981. Controlling replant disease of stone fruits in northeastern United States by preplant fumigation. Plant Dis. 65:859-864.

15. Mazzola, M. 1997. Identification and pathogenicity of Rhizoctonia spp. isolated from apple roots and orchard soils. Phytopathology 87:582-587.

16. Mazzola, M., Cook, R. J., Thomashow, L. S., Weller, D. M., and Pierson, L. S. 1992. Contribution of phenazine antibiotic biosynthesis to the ecological competence of fluorescent pseudomonads in soil habitats. Appl. Environ. Microbiol. 58:2616-2624.

17. Merwin, I. A., and Stiles, W. C. 1989. Root-lesion nematodes, potassium deficiency, and prior cover crops as factors in apple replant disease. J. Am. Soc. Hortic. Sci. 114:724-728.

18. Parmeter, J. R., Jr., Sherwood, R. T., and Platt, W. D. 1969. Anastomosis grouping among isolates of Thanatephorus cucumeris. Phytopathology 59:1270-1278.

19. Pieczarka, D. J., and Abawi, G. S. 1978. Effects of interaction between 
Fusarium, Pythium, and Rhizoctonia on severity of bean root rot. Phytopathology 68:403-408.

20. Savory, B. M. 1966. Studies on the occurrence and aetiology of specific replant diseases of perennial fruit crops. Ph.D. thesis. University of London, London.

21. Savory, B. M. 1966. Specific replant diseases causing root necrosis and growth depression in perennial fruit and plantation crops. Research Review No. 1. Commonw. Bur. Hortic. and Plantation Crops, East Malling, Maidstone, Kent, England.

22. Sewell, G. W. F. 1981. Effects of Pythium species on the growth of apple and their possible causal role in apple replant disease. Ann. Appl. Biol. 97:149-169.

23. Slykhuis, J. T., and Li, T. S. C. 1985. Response of apple seedlings to biocides and phosphate fertilizers in orchard soils in British Columbia. Can. J. Plant Pathol. 7:294-301.

24. Smith, T. J. 1995. Orchard Update. Washington State Univ. Coop. Ext. Bull., September issue. Pullman.

25. Stirling, G. R., Dullahide, S. R., and Nikulin, A. 1995. Management of lesion nematode (Pratylenchus jordanensis) on replanted apple trees. Aust. J. Exp. Agric. 35:247-258.

26. Sutton, T. B., Hayne, D. W., Sullivan, W. T., Nardacci, J. R., and
Klimstra, D. E. 1981. Causes of apple tree death in Henderson County, North Carolina. Plant Dis. 65:330-332.

27. Taylor, J. B., and Wallace, B. D. 1970. Root canker in stone fruit caused by the fungus Peniophora sacrata. Orchadist N. Z. 434:263-265.

28. Traquair, J. A. 1984. Etiology and control of orchard replant problems: A review. Can. J. Plant Pathol. 6:54-62.

29. Utkhede, R. S., Vrain, T. C., and Yorston, J. M. 1992. Effects of nematodes, fungi, and bacteria on the growth of young apple trees grown in apple replant disease soils. Plant Soil 139:1-6.

30. Wescott, S. W., III, Beer, S. V., and Israel, H. W. 1987. Interactions between actinomycete-like organisms and young apple roots grown in soil conducive to apple replant disease. Phytopathology 77:1071-1077.

31. Willett, M., Smith, T. J., Peterson, A. B., Hinman, H., Stevens, R. G., Ley, T., Tvergyak, P., Williams, K. M., Maib, K. M., and Watson, J. W. 1994. Growing profitable apple orchards in replant sites: An interdisciplinary team approach in Washington state. HortTechnology 4: 175-181.

32. Xi, K., Stephens, J. H. G., and Hwang, S. F. 1995. Dynamics of pea seed infection by Pythium ultimum and Rhizoctonia solani: Effects of inoculum density and temperature on seed rot and pre-emergence dampingoff. Can. J. Plant Pathol. 17:19-24. 